\title{
KOMUNIKASI PENDIDIKAN ANTARA GURU DAN MURID DALAM MEMBERIKAN KETERAMPILAN LITERASI (STUDY PADA SISWA-SISWI SDN 20 SUNGAILIAT BANGKA)
}

\author{
Yang Gusti Feriyanti, S,I.Kom, M.I.Kom \\ Stisipol Pahlawan 12 Sungailiat Bangka \\ Author correspondence : yanggoe5@ gmail.com
}

\begin{abstract}
Abstrak
Penelitian ini bertujuan untuk mengetahui kemampuan literasi siswa-siswi SDN 20 Matras Sungailiat dan bagaimana peran guru dalam memberikan motivasi berliterasi berbasis Bahasa Indonesia serta mencari solusi model pengembangan apakah yang efektif agar siswa-siswi SDN 20 memiliki kemampuan dalam berliterasi seperti membaca dan menulis dan memaparkan ide,gagasan serta kemampuan berkomunikasinya dalam bahasa Indonesia. Penelitian ini dilakukan pada siswa-siswi kelas V SDN sebanyak 36 orang, dan metodelogi yang yang digunakan adalah pendekatan deskriptif kualitatif. Istrumen penelitian ini dengan menggunakan observasi, hasil pengamatan,wawancara dan dokumen catatan lapangan .Tehnik analisnya dengan Hasil penelitian menunjukkan bahwa kemampuan literasi siswa-siswi SDN 20 minim serta minat membaca mereka rendah, padahal sarana perpustakaan sangat mendukung kegiatan literasi, terbukti banyaknya buku-buku bacaan yang tersedia di perpustakaan sekolah. Ada banyak ketersediaan dan ragam buku bacaan yang ada di perpustakaan.Peran guru sangat penting untuk terlibat dalam memberikan motivasi kepada siswa-siswi SDN 20 agar gemar membaca. Penelitian ini dapat menjadi alternatif bagi peneliti lainnya untuk meneliti dengan metode demonstrasi, bercerita atau model tindakan kelas media kartu.
\end{abstract}

Kata Kunci : Komunikasi Pendidikan, Literasi, Metode Cerita

\section{Abstract}

This study aims to determine the literacy skills of elementary school especially elementary school 20 Matras Sungailiat students and how the role of teachers in motivating Indonesian language-based literacy and find solutions to develop models that are effective so that the elementary school students have a basic literacy skill such as reading, writing, describing ideas, and communication skills in Indonesia. This research was conducted on 36 students in grade $V$, and the methodology used was a qualitative descriptive approach. The instruments of this study were using observations, interviews, and field notes. Analytical techniques with the results showed that the literacy ability and reading of elementary school students were low, even though the library facilities in the elementary school were very supportive of the literacy activities, as evidenced by a large number of book readings available in the school library. There is a lot of availability and variety of books available in the library. The role of the teacher is very important to be involved in motivating students of elementary school students so the student can enjoy while reading. This research can be an alternative for other researchers to examine the method of demonstration, storytelling, or a model of class media card action.

Keywords : Educational Communication, Literacy, Story Method.

\section{PENDAHULUAN}

Pendidikan merupakan suatu hal yang sangat penting dilaksanakan bagi generasi, mulai dari anak-anak, generasi muda serta seseorang yang ingin memperdalam ilmu pengetahuan sebab pendidikan bukan hanya sebagai proses pembelajaran saja tetapi dapat membawa perubahan cara berpikir individu. Melalui pendidikan formal anak-anak dapat menyerap informasi secara sistematis dan terarah serta mendapat pemahaman secara logis sehingga diharapkan dapat memberikan kualitas sumber daya manusia yang unggul. 
Salah satu pemenuhan kemajuan dunia pendidikan adalah kebutuhan terhadap literasi.Persaingan global juga menuntut kemampuan para siswanya untuk mampu berpikir secara kritis dan menganalisis setiap permasalahan yang timbul serta memiliki kemampuan mengelola informasi dengan baik.

Saat ini banyak program kegiatan literasi yang dilakukan oleh pemerintah daerah, dan pengiat anak muda Kabupaten Bangka untuk mengatasi rendahnya minat baca masyarakat Bangka Belitung. Melalui kegiatan literasi diharapkan siswa dapat mengakses, memahami dan menggunakan berbagai informasi secara cerdas, dengan demikian diharapkan dapat menumbuhkan budi pekerti peserta didik. Dengan membiasakan membaca buku, informasi sudah pasti akan mudah didapat, proses menimba ilmu juga akan mudah diserap, dan kita juga bisa menjadi bangsa yang bermartabat. Untuk mengenalkan kegiatan literasi, baik kepada masyarakat, sekolah, dan keluarga, melalui Gerakan Literasi Masyarakat, diberharapkan tumbuh minat baca masyarakat yang akan menjadi motivasi untuk meningkatkan minat baca siswa. Minat membaca di Indonesia masih rendah, hal ini dapat diketahui dari beberapa hasil penelitian bertaraf internasional yang telah diikuti oleh Indonesia untuk mengetahui kondisi bangsa Indonesia jika disejajarkan dengan negar-negara lain di dunia.

Berdasarkan kompas.com yang ditulis oleh: Mikhael Gewati Kondisi minat baca bangsa Indonesia memang cukup memprihatinkan. Berdasarkan studi "Most Littered Nation In the World" yang dilakukan oleh Central Connecticut State Univesity pada Maret 2016 lalu, Indonesia dinyatakan menduduki peringkat ke-60 dari 61 negara soal minat membaca. dengan kata lain minat baca masyarakat Indonesia disebut-sebut hanya sebesar 0,01 persen atau satu berbanding sepuluh ribu, angka ini berbanding terbalik dengan jumlah pengguna internet yang mencapai separuh dari total populasi penduduk Indonesia atau sekitar Rp 132,7 juta. Bahkan data yang dihimpun statista.com pada Januari 2018, disebutkan bahwa 44 persen populasi masyarakat Indonesia mengambil foto dan video menggunakan ponsel mereka.

Data tersebut menunjukkan bahwa kebiasaan membaca buku belum menjadi budaya bagi masyarakat Indonesia, dan ini merupakan tantangan bagi pemerintah, sekolah,pengajar serta orang tua untuk memulai suatu gerakan membaca. Ditingkat sekolah dasar kemampuan membaca merupakan hal penting bagi siswa untuk mengembangkan minat literasinya, karena melalui membaca memberikan kemudahan bagi siswa untuk belajar serta memahami materi yang diajarkan. Dalam hal ini kualitas dan inovasi Guru memiliki peran penting dalam mengembangakan model pembelajaran kepada muridnya serta memotivasi mereka untuk membaca.

Sekolah Dasar Negeri 20 Matras Sungailiat salah satu SD yang ada di Kabupaten Kepulauan Bangka Belitung berdasarkan hasil observasi peneliti pada saat berkunjung memiliki permasalahan dalam literasi. Literasi merupakan kemampuan individu dalam mengelolah dan memahami informasi ketika melakukan kegiatan membaca dan menulis. Dengan kata lain literasi adalah seperangkat ketrampilan dan kemampuan seseorang dalam membaca, menulis, berhitung, serta memecahkan masalah dalam kehidupan sehari-hari. membaca dan menulis seseorang.

Permasalahan yang terjadi adalah minimnya kemampuan siswa-siswi SDN 20 dalam menyampaikan pesan komunikasinya, seperti mengutarakan gagasannya dalam sebuah percakapan dan tulisan, hal itu dapat dilihat ketika peneliti melakukan wawancara dan mengajak mereka untuk menyatakan perasaan tentang cita-cita dan harapannya ketika mereka besar. Peneliti memberikan pena dan kertas dan mengajak mereka untuk menulis semua keinginannya dalam bentuk tulisan, melalui kegiatan literasi diharapkan siswa dapat menumbuhkan minat baca, meningkatkan kemampuan dalam proses berpikir, menambah pengetahuan, meningkatkan pemahaman dalam pengelolaan informasi serta siap beradaptasi dengan lingkungan perubahan sehingga kelak diharapkan mampu bersaing dalam menghadapi berbagai aspek perubahan. 
Literasi bukan hanya berkenaan dengan membaca dan menulis saja, tetapi ada unsur lain seperti : Bahasa, perbendaharaan kata atau kosa kata, serta kemampuan kognitif seseorang. Dalam literasi Bahasa sangat penting dalam menyampaikan pesan komunikasi kepada orang lain secara verbal maupun non verbal. Bahasa merupakan sistem simbol atau tanda yang disetujui untuk digunakan oleh sekelompok orang untuk menghasilkan arti. Hubungan antara simbol dan yang dipilih dan arti yang disepakati kadang berubah-ubah. Pentingnya Bahasa dalam masyarakat digital meningkatkan pentingnya berbahasa dalam berkomunikasi secara langsung menyatakan atau bertukar pikiran atau pandangan mengenai orang lain. Melalui Bahasa orang dapat menyampaikan emosi dan mengucapkan frasa. Bahasa memiliki peran penting dalam kegiatan berkomunikasi.

Sebagai sarana berkomunikasi Bahasa merupakan unsur penting dalam proses dimana suatu ide dialihkan dari sumber kepada suatu penerima atau lebih dengan maksud untuk mengubah tingkah laku mereka (Mulyana,2007). Bernard Berelson dan Gary A.Steiner menjelaskan bahwa komunikasi merupakan transmisi informasi, gagasan, emosi. Ketrampilan dan sebagainya dengan menggunakan simbol-simbol, kata-kata, gambar, figure, grafik dan sebagainya. Tindakan atau proses transmisi tersebut membutuhkan Bahasa.

Agar Bahasa dapat disampaikan dengan efektif, diperlukan sebuah strategi komunikasi yang baik, hal tersebut sangat penting mengingat literasi bukanlah hal yang mudah untuk dilakukan. Setiap kegiatan literasi yang dilakukan melibatkan banyak pihak seperti sekolah, guru, orang tua, masyarakat, sarana perpustakaan serta inovasi guru dalam system pembelajaran yang diberikan kepada siswa -siswinya. Program-program literasi tidak cukup menyediakan buku-buku bacaan tetapi keterlibatan guru dan siswa harus diterapkan serta melibatkan partisipasi pihak terkait agra kegiatan literasi dapat berjalan dengan baik. Pengenalan literasi dapat dilakukan melalui pelajaran Bahasa Indonesia melalui cerita. Sebuah cerita memberikan penjelasan secara verbal kepada orang lain.

Sujiono (dalam Tehupeiory dkk., 2014) metode bercerita adalah cara menyampaikan sesuatu dengan bertutur atau memberikan penerangan/penjelasan secara lisan melalui cerita. Dari pengertian tersebut dapat disimpulkan bahwa metode bercerita ialah sebuah karya sastra yang bisa disampaikan oleh orang dewasa atau pendidik dengan cara yang menarik dan menjadikan cerita sebagai kegiatan bermain bagi anak agar anak tidak bosan untuk mendengarkan isi cerita. Bercerita merupakan aspek pembentukan kepribadian dan manfaat bercerita adalah untuk mengembangkan kemampua berbicara dan memperkaya kosa kata sesorang khususnya anak-anak. Melalui cerita otomatis mengajarkan pembendaharaan kata. Bercerita dapat melatih dan memperkaya kemampuan berbahasa dan memahami struktur kalimat yang lebih kompleks.

\section{KAJIAN PUSTAKA}

\section{Komunikasi Pendidikan}

Manusia tidak dapat dipisahkan dengan komunikasi, untuk menyampaikan perasaan, ide, gagasaan, apa yang dipikirkan serta keinginannya manusia dapat menyampaikan secara langsung atau tidak lagsung, dan sarana yang dibutuhkan adalah komunikasi. Komunikasi yang efektif dapat terjadi jika maksud dan tujuan komunikator menyampaikan pesan kepada komunikan jelas, hal ini dapat mengurangi gangguan dalam proses berkomunikasi. Deddy Mulyana (2005:62) dalam bukunya Ilmu Komunikasi suatu pengantar mendefinisikan komunikasi menurut para ahli Bernard Berelson dan Gary A. Steiner menyatakan bahwa komunikasi adalah transmisi informasi, gagasan, emosi, keterampilan dan sebagainya, dengan menggunakan simbol-simbol, kata-kata, gambar, figure, grafik, dan sebagainya. Tindakan atau proses transmisi itulah yang biasanya disebut komunikasi. 
Sebagaimana yang kita ketahui bahwa Proses komunikasi adalah bagaimana sang komunikator menyampaikan pesan kepada komunikannya, sehingga dapat dapat menciptakan suatu persamaan makna antara komunikan dengan komunikatornya. Proses Komunikasi ini bertujuan untuk menciptakan komunikasi yang efektif (sesuai dengan tujuan komunikasi pada umumnya).

Secara garis besar, proses komunikasi juga melibatkan unsur komunikator sebagai pengirim pesan, oleh karena itu seorang komunikator perlu menyusun strategi atau tahapan-tahapan komunikasi yang strategis sehingga tujuan komunikasi dapat tercapai. Proses-proses komunikasi tersebut berkaitan dengan bahasa yang dijadikan penghubung antara komunikator dan komunikan. Mempelajari Bahasa secara tidak langsung akan menambah perbendaharaan kosa kata, Bahasa berlaku bagi orang yang menggunakannya.

Seiring dengan perkembangan ilmu pengetahuan dan tehnologi informasi, komunikasi juga dibutuhkan dalam dunia pendidikan. Komunikasi bukan hanya dipandang sekedar interaksi antara Guru dan Murid, tetapi bagaimana cara menyampaikan pesan komunikasi agar murid memahami dan memberikan makna terhadap pesan yang disampaikan oleh gurunya sehingga membawa pengaruh yang cukup besar terhadap pola-pola komunikasi yang terjadi. Komunikasi pendidikan adalah aspek komunikasi dalam dunia pendidikan, atau komunikasi yang terjadi pada bidang pendidikan. Jadi segala interaksi yang terhubung dalam semua aspek pendidikan yang saling berkaitan dan saling mendukung satu sama lain. Ketrampilan komunikasi yang harus dimiliki oleh setiap pelaku komunikasi yakni guru yang memberikan materi pembelajaran.

\section{Tiga Konseptualiasi Komunikasi}

John R. Wenburgb dan William W. Wilmot menyatakan bahwa setidaknya ada tiga kerangka pemahaman mengenai komunikasi yakni komunikasi sebagai tindakan satu arah, sebagai interaksi dan komunikasi sebagai transaksi. (Deddy Mulyana : 61)

1. Komunikasi sebagai tindakan satu arah, pesan yang disampaikan oleh pengirim pesan (soucer) kepada lawan komunikasinya baik secara langsung maupun dengan menggunakan media. Sebagai contoh ketika seorang guru menyampaikan pesan komunikasinya dan murid mendengarkan hal ini sudah dinyatakan bahwa proses komunikasi sudah terjadi, tetapi umpan balik yang diharapkan tidak terjadi karena dalam proses ini murid hanya mendengarkan saja tidak memberikan respon yang baik sehingga bentuk komunikasi satu arah ini dianggap kurang efektif dalam proses pembelajaran di kelas, tetapi lebih efektif apabila dilakukan bila guru memberikan materi melalui proses daring (dalam jaringan ) dengan mengunakan media, seperti E-learning.

2. Komunikasi sebagai Interaksi, yaitu pesan yang disampaikan dengan mengharapkan feed back (umpan balik). Komunikator menyampaikan pesan secara verbal dan nonverbal kemudian penerima pesan akan merespon dengan memberikan jawaban dan komunikator akan respon kembali dan proses komunikasi akan terus terjadi terus menerus. Komuniaksi sebagai interaksi dianggap sangat dinamis karena antara pelaku komunikasi saling memberikan umpan balik. Tetapi dalam dinamika komunikasi, proses interaksi dapat memberikan potensi bahwa antara sourcer dan receiver akan melakukan pengiriman dan penerimaan pesan secara bersamaan.

3. Komunikasi sebagai Transaksi, dalam konteks ini komunikasi adalah suatu proses personal karena makna atau pemahaman yang diperoleh pada dasarnya bersifat pribadi. Dalam komunikasi transaksional, komunikasi dianggap telah berlangsung bila seseorang telah menafsirkan perilaku orang lain, baik perilaku verbal maupun perilaku nonverbalnya. Penafsiran atas perilaku verbal dan nonverbal yang terjadi akan mengubah penafsiran orang lain atas pesan-pesan yang disampaikan oleh komunikator. Kelebihan dalam konsep transaksional adalah tidak membatasi kita pada komunikasi yang disengaja atau respon yang 
dapat diamati. Komunikasi dianggap telah berlangsung bila seseorang telah menafsirkan perilaku orang lain baik perilaku verbal maupun nonverbal.

\section{Literasi}

Secara etimologi literasi berasal dari bahasa Latin literatus (orang yang belajar) memiliki makna sebagai kemampuan melek huruf atau aksara seseorang dalam mengelola informasi. Pendapat lain mengatakan bahwa pengertian literasi adalah suatu kemampuan individu dalam mengolah dan memahami informasi ketika melakukan kegiatan membaca dan menulis. Dengan kata lain, literasi adalah seperangkat keterampilan dan kemampuan seseorang dalam membaca, menulis, berhitung, serta memecahkan masalah dalam kehidupannya sehari-hari.

Menurut UNESCO (The United Nations Educational, Scientific and Cultural Organization), arti literasi adalah seperangkat keterampilan nyata, terutama ketrampilan dalam membaca dan menulis, yang terlepas dari konteks yang mana ketrampilan itu diperoleh serta siapa yang memperolehnya. Dalam hal ini, arti literasi atau keberaksaraan bukan hanya sekedar membaca dan menulis saja, tetapi bagaimana seseorang berkomunikasi dalam masyarakat. Literasi bermakna praktik dan hubungan sosial yang terkait dengan pengetahuan, bahasa dan budaya. Literasi merupakan praktek dalam kehidupan sehari-hari, memahami setiap makna informasi yang diserap secara benar dan mendapatkan informasi yang akurat. Berdasarkan hal tersebut maka dapat ditarik benang merahnya bahwa literasi harus dimulai dari lingkungan terkecil yakni diri sendiri, keluarga dan sekolah.

Tujuan dari literasi adalah sebagai berikut :

1. Membantu meningkatkan pengetahuan masyarakat dengan cara membaca berbagai informasi bermanfaat.

2. Membantu meningkatkan tingkat pemahaman seseorang dalam mengambil kesimpulan dari informasi yang dibaca.

3. Meningkatkan kemampuan seseorang dalam memberikan penilaian kritis terhadap suatu karya tulis.

4. Membantu menumbuhkan dan mengembangkan budi pekerti yang baik di dalam diri seseorang.

5. Meningkatkan nilai kepribadian seseorang melalui kegiatan membaca dan menulis.

6. Menumbuhkan dan mengembangkan budaya literasi di tengah-tengah masyarakat secara luas.

7. Membantu meningkatkan kualitas penggunaan waktu seseorang sehingga lebih bermanfaat.

\section{Cerita}

Cerita merupakan merupakan karangan yang menuturkan perbuatan,pengalaman atau penderitaan orang,bagaimana terjadi suatu peristiwa atau kejadian baik yang sungguh-sungguh terjadi maupun yang hanya rekaan (nonfiksi). Bercerita adalah menyampaikan peristiwa atau kejadian dengan kata-kata, obyek, dan bunyi. Bercerita biasanya juga dipergunakan untuk memberikan informasi tentang kehidupan social anak dengan orang-orang disekitarnya. Bercerita merupakan Bahasa universal yang dapat mempengaruhi afeksi seseorang.

Jenis-jenis cerita :

1. Cerita mengenai Hewan

Hewan dapat dijadikan sebagai tokoh utama dalam menyampaikan cerita, hewan atau benda mati dikisahkan sebagai mahluk hidup layaknya manusia yang dapat berjalan, berpakaian, dan berkelakuan layaknya manusia. Dalam penokohan hewan tersebut pesan moral yang disampaikan oleh pencerita adalah pesan moral dan budi pekerti. 
2. Kehidupan sehari-hari atau nyata, menampilkan tokoh-tokoh simpatis yang menimbulkan empati anak-anak topic yang bisa diangkat seperti cerita sejarah,cinta dan persahabatan.

3. Cerita petualangan fantasi, adalah gabungan dari realita dan imajinasi. Kesan petualangan seakan-akan dimasukkan dalam kehidupan sehari-hari, segalanya terjadi, suatu permainan bisa menjadi nyata atau sebuah perahu yang membawa anak ke suatu pulau impian

4. Cerita tradisional meliputi cerita rakyat, mitos, legenda, cerita tentang monster dan fable. Cerita ini menampilkan pola-pola bercerita kaya akan Bahasa dan elemen-elemen fantasi, setting cerita bisa nyata maupun fiksi.

Manfaat cerita sebagai berikut ;

Melalui metode bercerita dalam model pengembangan literasi maka

1. Dapat meningkatkan keterampilan berbicara, dengan bercerita anak mengkomunikasikan suatu pesan kepada orang lain, sehingga lambat laun akan menumbuhkan keberanian anak dalam berbicara, bertanya dan mengungkapkan pendapat.

2. Untuk mengembangkan kemampuan Bahasa. Kemampuan berkomunikasi pada seseorang dipengaruhi oleh kemampuan berbahasanya. Melalui cerita anak akan mengenal beragam kosa kata istilah, ungkapan, serta struktur kalimat yang akan meningkatkan kemampuan berbahasanya.

3. Menambah wawasan, cerita mampu menyampaikan informasi dengan cara yang menyenangkan sehingga informasi tersebut dapat diserap dengan efektif. Anakpun dapat mengetahui apa yang belum diketahuinya melalui penyampaian yang lebih mudah dipahami.

4. Untuk meningkatkan kemampuan problem solving, selain dari pengalaman langsung, anak juga dapat belajar dari cerita. Cerita dapat membuat anak belajar berbagai kejadian, memahami karakter tokoh, serta sebab akibat hal tersebut dapat memperluas pengetahuan serta mempertajam logika anak, sehingga anak dapat mengatasi masalahnya sendiri sesuai dengan usianya.

5. Melalui cerita dapat merangsang imajinasi dan kreativitas, karena cerita memiliki ruang imajinasi yang luas. Imajinasi-imajinasi dalam cerita yang dapat memancing imajinasi anak sehingga pengembangan daya imajinasi ini sangat penting sebagai dasar pengembangan kreativitas anak.

6. Untuk mengembangkan kecerdasan emosi tertentu karakter di dalam cerita dapat membawakan beragam emosi sesuai dengan jalan cerita. Melalui karakter dalam cerita, anak dapat mengetahui apa saja yang dimaksud sedih, gembira, marah, takut, bingung, serta penyebab mengapa orang merasakan, mengendalikan dan megekspresikan emosi tertentu.

7. Untuk memperkenalkan nilai-nilai moral. Dalam cerita biasanya akan disisipkan nilai-nilai moral. Melalui cerita, pesan moral disampaikan dengan catra yang menyenangkan tidak memaksa dan mengintimidasi, serta sesuai dengan tahapan perkembangan dan pemahaman anak.

Kerangka Berpikir 
Permasalahan Model Pengem

Hasil

Penelitian

Bangan Lama

Penelitian/Solusi

\begin{tabular}{|l|}
\hline 1. Rendahnya \\
kemampuan literasi \\
siswa-siswi SDN \\
20 Matras \\
Sungailiat Bangka \\
2. Minat baca dan \\
menulis yang pasif \\
Serta sedikit \\
penguasaan \\
perbendaharaan \\
kata/kosa kata \\
3. Budaya membaca \\
belum diterapkan di \\
sekolah SDN 20 \\
4. Peran aktif Guru \\
dalam memberikan \\
motivasi kepada \\
siswa belum \\
maksimal \\
5. Tersedianya sarana \\
perpustakaan dan \\
buku bacaan tetapi \\
tidak \\
dimaksimalkan \\
fungsinya. \\
6. Belum ada upaya \\
dari guru untuk \\
menggali potensi \\
diri anak dalam \\
berliterasi. \\
\\
\\
\end{tabular}

\begin{tabular}{|c|}
\hline $\begin{array}{l}\text { Guru memberikan } \\
\text { materi pembelajaran } \\
\text { siswa hanya } \\
\text { mendengarkan dan } \\
\text { pasif }\end{array}$ \\
\hline $\begin{array}{l}\text { Pengenalan literasi } \\
\text { belum diterapkan } \\
\text { dalam sistem } \\
\text { pembelajaran }\end{array}$ \\
\hline $\begin{array}{l}\text { Cerita/dongeng belum } \\
\text { diterapkan } \\
\text { dalampengenalan literasi } \\
\text { kepada siswa-siswi baik } \\
\text { dari lingkungan keluarga } \\
\text { maupun di sekolah }\end{array}$ \\
\hline $\begin{array}{l}\text { Tidak ada tugas } \\
\text { merangkum dan menulis } \\
\text { cerita sebagai PR untuk } \\
\text { melatih kemapuan } \\
\text { kognitif siswa dalam } \\
\text { berpikir kritis. }\end{array}$ \\
\hline $\begin{array}{l}\text { Perpustakaan sebagai } \\
\text { tempat pajangan buku- } \\
\text { buku dan belum } \\
\text { dimaksimalkan sebagi } \\
\text { media pembelajaran }\end{array}$ \\
\hline
\end{tabular}

Model

pengembangan

baru melalui

cerita untuk

pengenalan

literasi berbasis

Bahasa Indonesia

Memperkuat

narasi siswa

melalui cerita

dengan tokoh-

tokoh

hewan/profesi

untuk

menanamkan

pesan moral dan

motivasi

membaca

Memanfaatkan

perpustakaan

sebagai

media/sarana

pembelajaran ke

dua pada saat

jam kosong atau

istirahat

Memaksimalkan partisipasi Guru

dalam

memotivasi

minat membaca

siswa-siswi SDN

20

\section{Metode}

Kegiatan Penelitian ini dilakukan di SDN 20 Matras Sungailiat Kabupaten Bangka dengan respondennya sebanyak 36 siswa-siswi murid kelas V. Adapun pemilihan responden dalam penelitian ini disesuaikan dengan judul penelitian yang penulis pilih yakni Komunikasi Pendidikan antara Guru dan Murid dalam Memberikan Keterampilan Literasi. Metode penelitian yang digunakan dalam penelitian ini adalah pendekatan deskriptif kualitatif. 
Creswell (2009) memyatakan bahwa penelitian kualitatif berarti proses eksplorasi dan memahami makna perilaku individu dan kelompok, menggambarkan masalah sosial atau masalah kemanusiaan. Proses penelitian mencangkup membuat pertanyaan penelitian dan prosedur yang masih bersifat. Sementara mengumpulkan data pada setting partisipan, analisis data secara induktif, membangun data yang parsial ke dalam tema dan selanjutnya memberikan interpretasi terhadap makna suatu data.kegiatan akhir adalah membuat laporan ke dalam struktur yang fleksibel.

Tehnik pengumpulan data dalam penelitian ini adalah dari data primer dan data sekunder yakni dengan melakukan observasi, pengamatan langsung pada objek penelitian, partisipan sebagai guru yang memberikan materi cerita, catatan lapangan dan interview tidak berstruktur kepada Guru dan siswa-siswi SDN 20 Matras sungailiat Kabupaten Bangka Belitung.

\section{Temuan dan Pembahasan}

Hasil temuan yang peneliti dapatkan selama melakukan observasi lapangan di SDN 20 Matras Sungailiat Bangka adalah dengan melakukan Pengamatan secara langsung dan observasi yang dilakukan terhadap kegiatan siswa-siswi selama proses belajar dan pada jam istirahat. Pada saat jam kosong siswa-siswi SDN 20 lebih banyak menghabiskan waktu dengan bermain di kelas, di halaman sekolah dan di kantin. Tidak ada siswa-siswi yang membaca buku di ruang perpustakaan yang terletak dekat ruangan Guru. Pada sesi pembelajaran di kelas peneliti berlaku sebagai Guru Bahasa Indonesia dan mengajak siswa-siswi untuk berkomunikasi melalui tanya jawab dengan menggunakan bahasa Indonesia agar mudah dipahami oleh siswa-siswi kelas V.

Model pembelajaran yang dilakukan oleh peneliti adalah dengan bercerita. Sebelum memulai bercerita peneliti memberikan beberapa pertanyaan seputar pengetahuan mereka tentang macam-macam cerita, sebanyak 12 siswa menjawab dan memilih cerita hewan kancil dan buaya dan 4 orang memilih cerita malinkundang selebihnya sebanyak 20 siswa pasif menjawab dan belum pernah mendengar cerita. Berdasarkan permintaan siswa SD kelas V maka peneliti menceritakan tokoh kancil dan buaya dengan penekanan pesan moral yang akan disampaikan dalam cerita tersebut. Pada saat bercerita peneliti mengamati ekpresi dari wajah siswa-siswa kelas V dan sebanyak 30 orang menyimak dengan baik dengan ekspresi wajah serius sementara 4 orang tertidur di dalam kelas dan 2 siswa meninggalkan kelas karena harus ikut latihan berbaris. Selama 30 menit penulis bercerita dan setelah itu peneliti memberikan mereka buku tulis dan pena sebanyak 34 buku dan pena dan meminta siswa-siswi tersebut untuk menulis cerita berjudul cita-citaku.

Dari 34 buku yang peneliti berikan hanya 5 siswa yang mampu menulis cerita dengan baik dan mengkomunikasikan ide, gagasan dalam pikiran mereka dalam bentuk tulisan. Peneliti juga ikut berpartisipasi memotivasi siswa dengan membantu perbendaharaan kata-kata sehingga tulisan mereka dapat dihasilkan sebuah cerita. Sebanyak 30 siswa pasif dan tidak memiliki kemampuan untuk mengkomunikasikan gagasan dalam bentuk tulisan. Penilaian yang dilakukan oleh peneliti kepada siswa-siswi kelas V adalah dengan menilai tulisan berbentuk cerita. Dari beberapa anak tidak menulis karena tidak paham dan kesulitan bagaimana menulis tema cita-cita dalam bentuk tulisan.

Berdasarkan dari temuan tersebut peneliti melakukan pendekatan secara personal, menstimulus tentang tokoh pilot, tentara dan dokter serta mengajari mereka bagaimana menulis secara berstruktur dimulai dengan profile diri dan mengungkapkan keinginan /cita-cita mereka. Peneliti menceritakan profile profesi dan siswa-siswi tersebut lebih berminat untuk menulis karena peneliti memberikan reward bahwa siapa yang dapat menulis lebih banyak maka akan diberikan hadiah kotak pensil dan dari 34 siswa yang hadir hanya 3 yang mampu menulis lebih banyak, selebihnya hanya menulis 4 kalimat.

Berdasarkan hasil wawancara tidak berstruktur peneliti dengan beberapa guru bahwa perpustakaan jarang digunakan untuk kegiatan membaca walaupun banyak buku yang tersedia 
dengan alasan bahwa siswa-siswi SDN 20 minat membacanya rendah, walaupun diberikan kesempatan untuk membaca diperpustakaan, tetapi guru tidak terlibat langsung untuk mendorong dan membangun minat baca siswa-siswi karena tugas Guru sudah banyak dalam proses belajar dan mengajar.

Berdasarkan hal tersebut peneliti menyimpulkan bahwa minimnya minat baca dan perbendaharaan kosa kata anak serta kurangnya motivasi, partisipan, serta inovasi dari guru untuk membudayakan kegiatan membaca dan menulis menunjukkan bahwa kemampuan seni literasi siswa-siswi kelas V sangat rendah. Oleh karena itu harus ada inovasi dalam model pengembangan belajar literasi melalui pelajaran Bahasa Indonesia seperti komunikasi yang dilakukan harus dua arah dan transaksional, Guru berperan sebagai komunikator yang memiliki kemampuan literasi yang baik dalam memberikan narasinya di kelas, materi pembelajaran dapat diberikan dalam bentuk pemaparan dengan tehnik bercerita sehingga siswa-siswi tidak bosan dan mengantuk, atau guru berperan memberikan reward kepada siswa-siswi berbentuk pujian sehingga mereka termotivasi untuk belajar dan mampu menyampaikan gagasan nya baik secara verbal dan nonverbal.

Komunikasi pendidikan bukan hanya dipandang sebagai proses memberikan materi saja, tetapi bagaimana Guru sebagai komunikator dapat menjadi panutan dan menginspirasi siswa-siswi agar memiliki ketrampilan dalam menyerap mata pelajaran dengan umpan balik dua arah. Efektivitas komunikasi dapat dilihat apabila antara Guru dan murid sama-sama memahami pesan komunikasi dan merespon balik sehingga dapat mengubah perilaku sesuai dari tujuan komunikasi yang diinginkan. Kemampuan literasi yang baik dapat membantu proses komunikasi, interaksi dan proses pembelajaran dalam pendidikan.

\section{KESIMPULAN}

Berdasarkan hasil dari pelaksanaan penelitian selama melakukan observasi lapangan maka dapat disimpulkan bahwa :

1. Kurangnya minat membaca dan menulis siswa-siswi SDN 20 kelas V menyebabkan kemampuan literasi siswa-siswi tersebut rendah

2. Partisipasi guru belum maksimal dalam memotivasi siswa-siswi SDN 20 untuk membiasakan budaya membaca.

3. Model pembelajaran masih dilakukan secara umum yaitu siswa disuruh menghapal dan guru tidak terlibat memberikan motivasi berliterasi.

4. Siswa-siswi lebih tertarik dan pencapaian target yang diinginkan oleh peneliti tercapai melalui pemberian materi bercerita tentang tokoh keprofesian.

\section{Saran}

1. Untuk mengembangkan minat membaca dan menulis siswa maka harus ada keterlibatan dalam partisipasi Guru, siswa dalam interaksi kelas, Guru harus menggunakan strategi bercerita yang berhubungan dengan materi pembelajaran hingga menarik perhatian siswa-siswi untuk melatih kemampuan menyimak, membaca serta menstimulus kemampuan berbicara di depan kelas.

2. Guru seharusnya melakukan pendekatan personal dan memberi motivasi dengan memberikan reward kepada siswa-siswi agar mereka tertarik untuk menulis serta merespon setiap pertanyaan yang diajukan oleh siswa.

3. Menstimulus siswa-siswi untuk menulis cerita dan memaparkan ceritanya di kelas sehingga siswa yang lain dapat menyimak serta memberi umpan balik kepada siswa yang membaca di kelas. 
4. Budaya membaca di perpustakaan harus dilakukan bersama dengan melibatkan guru untuk memberi tugas menulis isi materi buku kepada siswa dan melakukan komunikasi (dialog) Tanya jawab sehingga siswa-siswi dapat berpikir kritis.

\section{DAFTAR PUSTAKA}

Dhea Anatasya, dkk. 2018. "Pembelajaran Bahasa Indonesia di Sekolah Dasar".

Hardiningtyas,Tri dkk. 2018. Literasi Seni Mengelola Budaya Baca Tulis. Surakarta: Yuma Pustaka.

Hyang Su Oh, 2019. Bicara Itu Ada Seninya. Jakarta: Bhuana Ilmu Populer.

Mulyana,Deddy. 2005. Ilmu Komunikasi Suatu Pengantar. Bandung: PT Remaja Rosdakarya.

Inda Fitryarini. 2016. "Literasi Media Pada Mahsiswa Prodi Ilmu Komunikasi Universitas

Mulawarman”. Jurnal Komunikasi. Volume 8 Nomor 1. Kalimantan Timur: Universitas Mulawarman.

Nofrion. 2018. Komunikasi Pendidikan Penerapan Teori dan Konsep Komunikasi dalam Pembelajaran. Jakarta: Prenada Media Group.

Rakhma Jalaluddin,Ibrahim Subandy Idi. 2017. Metode Penelitian Komunikasi. Bandung: Simbiosa Rekatama Media.

Sugiono. 2018. Metode Penelitian Evaluasi Pendekatan Kualitatif. Bandung: Alfabeta.

Sinsin Kartini. 2010. "Metode Bercerita dalam Pembelajaran Menyimak di Kelas V Sekolah Dasar". Jurnal Edu Humaniniora. Volume 2 Nomor 2. Bandung: Universitas Pendidikan Indonesia. 